Int. J. Electrochem. Sci., 11 (2016) $8848-8860$

International Journal of

ELECTROCHEMICAL

SCIENCE

www.electrochemsci.org

\title{
Antioxidant Potential of Hydroxycinnamic Acids in Advanced Oxidation Processes
}

\author{
Anna Masek ${ }^{1, *}$, Ewa Chrzescijanska ${ }^{2}$, Malgorzata Latos ${ }^{1}$, Marian Zaborski ${ }^{1}$ \\ ${ }^{1}$ Technical University of Lodz, Institute of Polymer and Dye Technology, Faculty of Chemistry, 90- \\ 924 Lodz, ul. Stefanowskiego 12/16, Poland \\ ${ }^{2}$ Technical University of Lodz, Institute of General and Ecological Chemistry, Faculty of Chemistry, \\ 90-924 Lodz, ul. Zeromskiego 116, Poland \\ "E-mail: anna.masek@p.lodz.pl
}

doi: $10.20964 / 2016.10 .12$

Received: 17 June 2016 / Accepted: 27 July 2016 / Published: 6 September 2016

The aim of the study was to describe the characteristics of a natural antioxidant derived from the group of the hydroxycinnamic acids (sinapic and ferulic acid). Electrochemical methods and other spectrophotometric assays were studied for the analysis to determine the mechanism of action in the advanced oxidation processes. ABTS and DPPH methods has been allowed to access the potential of natural compounds to scavenge free radicals, but the methods of FRAP and CUPRAC possible to determine the potential for reduction of copper and iron ions. The curve of the differential pulsed and cyclic voltammograms found that ferulic acid is oxidized in one step electrode, and sinapic acid in two stages electrode. Sinapic acid oxidizes easily with superior abilities of antioxioxidant. Based on the survey, it was found that both tested hydroxycinnamic acids have high potential of antioxidants.

Keywords: ferulic acid; synapic acid; electrooxidation; antioxidant; spectrophotometric assay

\section{FULL TEXT}

(C) 2016 The Authors. Published by ESG (www.electrochemsci.org). This article is an open access article distributed under the terms and conditions of the Creative Commons Attribution license (http://creativecommons.org/licenses/by/4.0/). 